\title{
The Science of Nature
}

The final publication is available at Springer via http://dx.doi.org/10.1007/s00114-016-1383-y

\section{Ca $\mathrm{L}_{2,3}$-edge XANES and Sr K-edge EXAFS study of hydroxyapatite and fossil bone apatite}

\author{
I. M. Zougrou ${ }^{1}$, M. Katsikini ${ }^{1 *}$, M. Brzhezinskaya ${ }^{2}$, F. Pinakidou ${ }^{1}$, L. Papadopoulou ${ }^{3}$, \\ E. Tsoukala ${ }^{3}$, E. C. Paloura ${ }^{1}$ \\ ${ }^{1}$ School of Physics, Department of Solid State Physics, Aristotle University of Thessaloniki, 54124 \\ Thessaloniki, Greece. \\ ${ }^{2}$ Main Department Scientific-Technical Infrastructure II, Helmholtz Zentrum Berlin, 12489 Berlin, \\ Germany. \\ ${ }^{3}$ School of Geology, Aristotle University of Thessaloniki, 54124 Thessaloniki, Greece.
}

*Corresponding author: Maria Katsikini, e-mail: katsiki@auth.gr; Tel: +30- 2310- 998500; Fax: +302310- 998028

\begin{abstract}
:
Upon burial, the organic and inorganic components of hard tissues such as bone, teeth and tusks are subjected to various alterations as a result of interactions with the chemical milieu of soil, groundwater and presence of microorganisms. In this study, simulation of the $\mathrm{Ca} L_{2,3}$-edge X-Ray Absorption Near Edge Structure (XANES) spectrum of hydroxyapatite, using the CTM4XAS code, reveals that the different symmetry of the two non-equivalent $\mathrm{Ca}_{(1)}$ and $\mathrm{Ca}_{(2)}$ sites in the unit cell, gives rise to specific spectral features. Moreover, $\mathrm{Ca} L_{2,3}$-edge XANES spectroscopy is applied in order to assess variations in fossil bone apatite crystallinity due to heavy bacterial alteration and catastrophic mineral dissolution, compared to well-preserved fossil apatite, fresh bone and geologic apatite reference samples. Fossilization-induced chemical alterations are investigated by means of $\mathrm{Ca}$ $L_{2,3}$-edge XANES and Scanning Electron Microscopy (SEM) and are related to histological evaluation using optical microscopy images. Finally, the variations in the bonding environment of $\mathrm{Sr}$ and its preference for substitution in the $\mathrm{Ca}_{(1)}$ or $\mathrm{Ca}_{(2)}$ sites upon increasing the $\mathrm{Sr} / \mathrm{Ca}$ ratio is assessed by $\mathrm{Sr}$ K-edge Extended X-Ray Absorption Fine Structure (EXAFS) spectroscopy.
\end{abstract}

Keywords: Fossils, bone, apatite, $\mathrm{Ca}, \mathrm{Sr}$, XAFS, CTM4XAS 


\section{Introduction}

The study of biological apatite is of significant importance for a wide range of disciplines including biomedicine, forensics, zoology, archaeology and palaeontology. Bone is a composite material that consists of low-crystallinity carbonated hydroxyapatite (HA), $\mathrm{Ca}_{10}$ ${ }_{x}\left[\left(\mathrm{PO}_{4}\right)_{6-2 x}\left(\mathrm{CO}_{3}\right)_{2 \mathrm{x}}\right](\mathrm{OH})_{2}$, embedded in a collagen matrix (Wopenka and Pasteris 2005). $\mathrm{X}$ ray absorption fine structure (XAFS) spectroscopy is a powerful technique for the study of biominerals since it is element specific and suitable for structural characterization of both disordered and crystalline mineral phases. More specifically, X-ray Absorption Near Edge Structure (XANES) spectroscopy at the Ca $L_{2,3}$-edge, yields chemical fingerprint information, as determined from the site symmetry and bonding configuration of $\mathrm{Ca}^{2+}$, and has provided valuable knowledge on the processes of biomineralization in a variety of Ca-containing biominerals (Naftel et al. 2001; Benzerara et al. 2004; Politi et al. 2004; Beniash et al. 2009). However, despite the increasing interest in biomineral characterization, the origin of specific features in the hydroxyapatite $\mathrm{Ca} L_{2,3}$-edge XANES spectrum has not been yet well understood.

The assessment of apatite crystallinity by means of $\mathrm{Ca} L_{2,3}$-edge XANES spectroscopy can be used to elucidate the process and rate of apatite crystallization in fresh skeletal parts as well as the effect of geochemical and environmental conditions on the apatite crystal size in archaeological and palaeontological vertebrate skeletal remains. Politi et al. (2008) have shown that the calcite crystals in sea urchin larval spicules were formed from an intermediate amorphous calcium carbonate phase. The intensity and position of the two peaks that appear prior to the main $L_{3}$ and $L_{2}$ edges in the $\mathrm{CaCO}_{3}$ spectrum were sensitive to the degree of crystallization. In the same context, Beniash et al. (2009) showed that newly formed enamel consists of amorphous calcium phosphate which is later transformed into apatitic crystals and observed that the energy position of the peak that appears prior to the $L_{3}$ edge is more sensitive to the crystallinity of the disordered calcium phosphate. In archaeological and palaeontological bone further changes in apatite crystallinity, related to environmental and geochemical conditions, are observed (Smith et al. 2007; Dumont et al. 2011).

Collagen hydrolysis and bioerosion processes, occurring during the early stages of bone burial, degrade collagen and expose the surface of apatite crystals facilitating their dissolution (Hedges 2002; Collins et al. 2002; Jans 2008). Post-deposition stabilization and preservation of bone is achieved by the growth of new apatite crystals, which are thermodynamically more stable and less soluble, resulting in a reduced bone porosity. This recrystallization process occurs simultaneously with collagen degradation in bones exposed on soil surfaces (Tuross et al. 1989; Trueman et al. 2004) and is accompanied by incorporation of various ions in the apatite matrix via diffusion or ion exchange (Pate et al. 1989; Kohn 2008; Trueman 2008). Chemical alterations such as substitution of $\mathrm{OH}^{-}$by $\mathrm{F}^{-}$and reduction of carbonate content increase the apatite crystallinity and provide greater chemical stability (LeGeros and Tung 
1983; LeGeros et al. 2006) while the geochemical conditions of the deposition site, as for example waterlogged areas (Reiche et al. 2002), can also affect the size of the apatite crystals in sub-fossil bone, resulting in sizes comparable to that in fossil bones. Therefore, the apatite crystallinity depends on many factors such as the amount of preserved collagen, the sediment $\mathrm{pH}$ and redox potential, hydrology and solution composition, the bone porosity, the microbial activity, exposure on soil surface and the pre-burial environmental conditions. Berna et al. (2004) reported that dissolution and recrystallization of bone apatite in aqueous solution occurs at $\mathrm{pH}$ values between 7.6 and 8.1 at $25^{\circ} \mathrm{C}$. Such $\mathrm{pH}$ conditions in the local chemical milieu are met both during the early diagenetic stage, due to the high phosphate content and collagen decay, but also during the late diagenesis when $\mathrm{pH}$-dependent mineral precipitation occurs (Pfretzschner 2004). Although the crystal size of fresh, archaeological and fossil bone has been extensively investigated (Bartsiokas and Middleton 1992; Dumont et al. 2011), bioerosion, which is one of the various factors that affect bone crystallinity, has been scarcely studied and deserves further investigation. Smith et al. (2007) reported that bones without any microbial attack have higher crystallinity than those affected by bioerosion processes.

Hydroxyapatite, $\mathrm{Ca}_{10}\left(\mathrm{PO}_{4}\right)_{6}(\mathrm{OH})_{2}$, adopts the hexagonal symmetry (space group $\left.\mathrm{P} 6_{3} / \mathrm{m}\right)$. Two non-equivalent $\mathrm{Ca}$ sites, denoted as $\mathrm{Ca}_{(1)}$ and $\mathrm{Ca}_{(2)}$, exist in the unit cell and the formula can be written as $\mathrm{Ca}_{(1) 4} \mathrm{Ca}_{(2) 6}\left(\mathrm{PO}_{4}\right)_{6}(\mathrm{OH})_{2}$. The $\mathrm{Ca}_{(1)}$ and $\mathrm{Ca}_{(2)}$ polyhedra are arranged perpendicular to the c-axis and are positioned hexagonally around a central hexad (Fig. 1a). $\mathrm{Ca}$ atoms occupying the $\mathrm{Ca}_{(1)}$ site (with point symmetry 3 ) are coordinated with nine oxygen atoms as shown in Fig. 1b, and form a tricapped trigonal prismatic polyhedron. Ca atoms located in the $\mathrm{Ca}_{(2)}$ site (with point symmetry $m$ ) are coordinated with six oxygen atoms and one hydroxyl oxygen atom, as shown in Fig. 1c, forming a distorted octahedron-type polyhedron. The $\mathrm{OH}^{-}$ions are positioned in columns in the center of this hexad and parallel to the $c$-axis. The $\mathrm{Ca}_{(1)}$ atoms form a honeycomb structure and the $\mathrm{Ca}_{(2)}$ atoms form triangles which are both centred on the $\mathrm{OH}^{-}$column. The adjacent $\mathrm{Ca}_{(1)}$ and $\mathrm{Ca}_{(2)}$ polyhedra are linked through shared oxygen atoms of the $\mathrm{PO}_{4}$ tetrahedra while substitution of the $\mathrm{OH}^{-}$ions by $\mathrm{F}^{-}$or $\mathrm{Cl}^{-}$ions affects mainly the $\mathrm{Ca}_{(2)}$ polyhedron (Hughes 1989). The different bonding of $\mathrm{Ca}$ in the $\mathrm{Ca}_{(1)}$ and $\mathrm{Ca}_{(2)}$ sites is expected to give rise to distinct spectral features in the $\mathrm{Ca} L_{2,3}$-edge XANES spectrum of HA. Towards the identification of these features, we resorted to multiplet calculations using the CTM4XAS code (Stavitski and de Groot 2010). Since several biomaterials, such as bone and teeth, consist of carbonated HA, understanding of the origin of the features observed in the $\mathrm{Ca} L_{2,3}$-edge XANES spectrum of $\mathrm{HA}$ is of significant importance for biological, biomedical, archaeological and palaeontontological studies. $\mathrm{Ca}$ $L_{2,3}$-edge XANES spectroscopy is used in order to assess the degree of crystallinity in fossil bone apatite affected by heavy bacterial alteration and catastrophic mineral dissolution, compared to well-preserved fossil apatite, fresh bone and geologic apatite reference samples as well as for the investigation of structural alterations induced by ionic substitutions in the HA lattice due to fossilization processes. 
Apart from the apatite crystal size and lattice disorder, the effect of minor incorporation of elements with different ionic radii, such as $\mathrm{Sr}^{2+}, \mathrm{K}^{+}, \mathrm{Mg}^{2+}, \mathrm{Pb}^{2+}$, on the lattice parameters should be also considered (Keenan et al. 2015). The effect of Sr content on the HA lattice has been studied in solid state diffusion-produced Sr-HA and the results have shown a linear increase in the lattice parameters upon increasing of the Sr content, whereas crystallinity, as defined by the mean crystal size, appears to vary with Sr concentration (Bigi et al. 2007; Li et al. 2007). It is however important to study the effect of Sr substitution in actual biological materials and in this respect, fossil bones are ideal specimens due to their ability to incorporate varying amounts of $\mathrm{Sr}$ during apatite recrystallization. Many studies have investigated the preference for $\mathrm{Sr}$ substitution in the two non-equivalent sites of $\mathrm{Ca}$ in the HA structure with contradicting results (O'Donell et al. 2008; Terra et al. 2009; Zeglinski et al. 2012). The site preference for $\mathrm{Sr}$ substitution in the larger volume of the $\mathrm{Ca}_{(1)}$ site or in the smaller $\mathrm{Ca}_{(2)}$ site of the HA structure is an important parameter as it will induce different lattice strain due to the different co-ordination geometry. Towards this direction, we study the $\mathrm{Ca}$ site preference for $\mathrm{Sr}$ substitution by means of $\mathrm{Sr}$ K-edge EXAFS spectroscopy which probes the structural and bonding environment of Sr. Moreover, Optical Microscopy (OM) and Scanning Electron Microscopy (SEM)-Backscattered Electrons (BSE) imaging are used to evaluate the state of histological preservation, as well as to identify the type and extent of microbial alterations. SEM with energy dispersive X-ray spectroscopy (SEM-EDX) is used to determine the chemical composition of the fossil apatite and secondary precipitated or deposited phases while X-Ray Fluorescence (XRF) spectroscopy provides complementary to the SEM-EDX information on bulk chemical concentration of heavier elements.
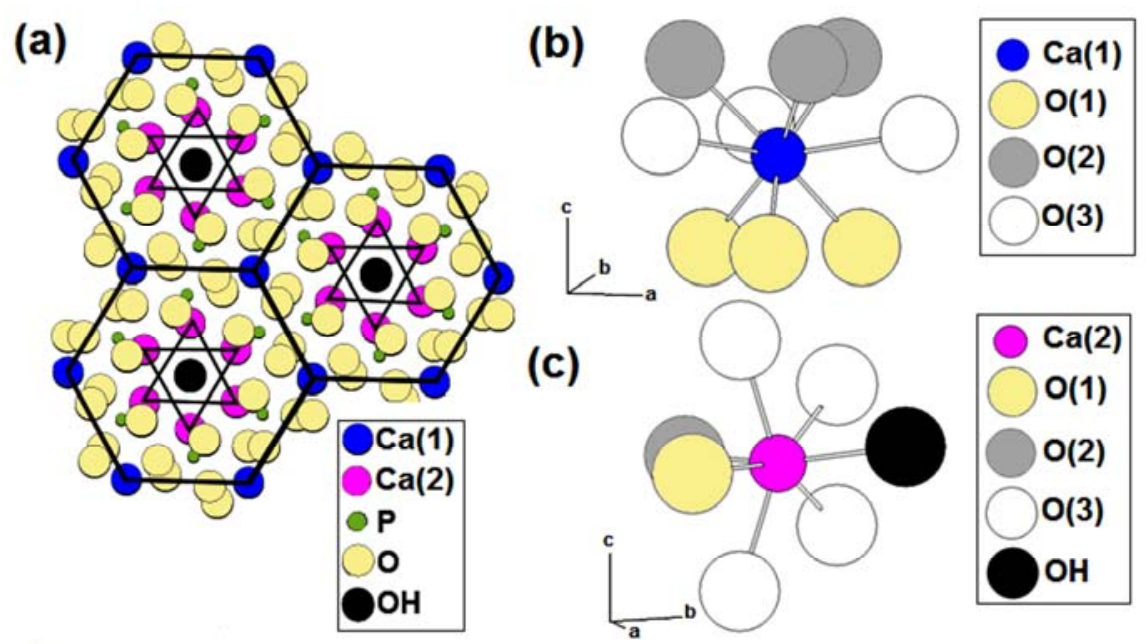

Figure 1. (a) Structure of hydroxyapatite projected on the (001) plane, (b) coordination geometry of the $\mathrm{Ca}_{(1)}$ site, (c) coordination geometry of the $\mathrm{Ca}_{(2)}$ site. 


\section{Materials and Methods}

\section{Fossil bone specimens}

The studied specimens are fossil bone fragments of Late Miocene large mammals (Turolian age, 5.3-9 Ma) from the excavation site of Kryopigi in Kassandra, Chalkidiki, Greece (Tsoukala and Bartsiokas 2008). The macroscopic colour of the fossil samples varies from white (KR-2, KR-8) to dark blue with grey areas (KR-1, KR-3, KR-7), whereas the KR-4, KR-6 and KR-9 samples are white with areas of blue staining. The medullar cavity has been preserved in four samples (KR-1, KR-2, KR-5, KR-7) and is filled with depositional sediments. The degree of bioerosion-induced diagenetic alteration in compact bone histology was characterized using the Oxford Histological Index (OHI) proposed by Hedges et al. (1995). According to the OHI, the percentage of intact bone preserved in Haversian bone histology is classified into 5 categories, ranging from badly preserved bones with $\mathrm{OHI}=0$ (no original features, other than vascular canals, can be identified) to very well-preserved bones with $\mathrm{OHI}=5$ (virtually indistinguishable from a fresh bone). Bioerosion borings were characterized according to Hackett (1981) and Davis (1997) while porosity was described according to Turner-Walker et al. (2002) and Smith et al. (2007). Two types of porosities are considered: microbial or $m$-porosity that refers to pores with diameter ranging between 0.1 $8.5 \mu \mathrm{m}$ and dissolution or $l$-porosity that refers to pores with diameter between $8.5-70 \mu \mathrm{m}$.

\section{Reference materials}

The reference materials used for the evaluation of $\mathrm{Ca} L_{2,3}$-edge XANES spectra of fossil bones include pure HA, fresh calf bone and geological apatites from Norway, Quebec and Durango. The latter reference samples were used due to their ability to incorporate a vast amount of substitute ions in the apatite lattice. Finally, calcite $\left(\mathrm{CaCO}_{3}\right)$ reference was used because it is a common secondary mineral in cavities of palaeontological bones.

\section{Instrumentation}

The XANES measurements at the $\mathrm{Ca} L_{2,3}$-edge were conducted at the Russian-German Beamline of the BESSY II synchrotron radiation storage ring of the Helmholtz Zentrum Berlin (Molodtsov et al. 2009). The measurements were performed under ultrahigh vacuum conditions $\left(7 \times 10^{-10}\right.$ Torr $)$. The incident beam of monochromatic radiation was impinging at $45^{\circ}$ to the sample surface while the size of the focused spot on the sample was $0.1 \times 0.2 \mathrm{~mm}^{2}$. The spectra were recorded in the total electron yield (TEY) mode by varying the energy of the incident photons and measuring the sample's drain current. The energy resolution of the monochromator in the range of the Ca $L$-edge XANES spectra was $0.1 \mathrm{eV}$. The Sr K-edge EXAFS and XRF spectra were recorded at the $\mathrm{C}$ beamline of the DORIS storage ring at HASYLAB in the fluorescence yield mode under atmospheric pressure using a seven-element fluorescence detector. The synchrotron radiation beam was monochromatized with a Si(111) 
double crystal monochromator. The photon flux on the sample was $10^{9}$ photons/s with a beam size of $6 \times 1 \mathrm{~mm}^{2}$. The XRF spectra were recorded using an excitation beam of $17 \mathrm{keV}$. The EXAFS and XRF spectra were recorded from the external side of the bulk samples and carry bulk information from the periosteal area.

The SEM measurements were obtained using a Jeol JSM-840A scanning electron microscope equipped with an energy-dispersive X-ray spectrometer operating at $20 \mathrm{kV}$ accelerating voltage and $0.4 \mathrm{~mA}$ probe current in the back-scattering electron analysis mode. Pure Co was used as an optimization element and a standard for the analyses of the mineral phases (registered standard number 1773, Micro-Analysis Consultants Ltd). Wollastonite, $\mathrm{Na}_{2} \mathrm{O}$, $\mathrm{K}_{2} \mathrm{O}, \mathrm{Rb}_{2} \mathrm{O}$ and $\mathrm{SrO}$ were used as reference samples for the detection of $\mathrm{Ca}, \mathrm{Na}, \mathrm{K}, \mathrm{Rb}$ and $\mathrm{Sr}$ respectively in the SEM-EDX measurements.

\section{Sample preparation}

For the Ca $L_{2,3}$-edge XANES measurements the reference samples and fossil compact bone remains were powdered in air and rubbed into a scratched surface of a pure In foil (substrate) in order to minimize charging effects. The Sr K-edge XAFS and XRF spectra were recorded without any special sample preparation. For the OM and SEM measurements the samples were embedded in epoxy resin, cut in thin sections and polished to a thickness of 30-50 $\mu \mathrm{m}$. Prior to SEM characterization, the sections were coated with a thin carbon layer.

\section{Spectra evaluation}

The Ca $L_{2,3}$-edge XANES spectra were subjected to linear background subtraction and normalization to the edge jump. The bone specimens and the apatite reference spectra were calibrated by setting the $L_{2}$ edge at $352.5 \mathrm{eV}$ for better comparison of the differences due to chemical composition, whereas the calcite reference was calibrated by setting the main $L_{2}$ (named as $b_{2}$ ) peak at $352.6 \mathrm{eV}$ according to Benzerara et al. (2004) The spectra were fitted using the PEAKFIT software while the $\mathrm{Ca} L_{2,3}$-edge multiplet simulations were carried out using the charge transfer multiplet CTM4XAS code (Stavitski and de Groot 2010). The analysis of the Sr K-edge EXAFS spectra was conducted using the FEFF8 package (Newville et al. 1995; Ankudinov et al. 1998). The model of hydroxyapatite, $\mathrm{Ca}_{10}\left(\mathrm{PO}_{4}\right)_{6}(\mathrm{OH})_{2}$, where $\mathrm{Sr}$ substitutes for the central $\mathrm{Ca}$ absorbing atom, was used for the fitting of the $\mathrm{Sr} K$-edge spectra. The XRF spectra were fitted with the WinQXAS package (Vekemans et al. 1994) after taking into account corrections for escape peaks. The weight ratio, $\mathrm{C}_{\mathrm{A}} / \mathrm{C}_{\mathrm{B}}$, for two elements, A and B, was determined as in previous studies (Zougrou et al. 2014). 


\section{Results}

\section{CTM4XAS simulation of the Ca $L_{2,3}$-edge XANES spectrum of HA}

The features of the XANES spectra recorded at the $L_{2,3}$-edge of $\mathrm{d}^{0}$ elements, such as $\mathrm{Ca}^{2+}$, in octahedral $\left(\mathrm{O}_{\mathrm{h}}\right)$ symmetry, have been previously described by de Groot et al. (1990) using the atomic multiplet theory and taking into account intra-atomic interactions such as the $2 \mathrm{p}$ core hole and $3 \mathrm{~d}$ spin-orbit coupling, Coulomb repulsion and exchange interactions as well as the crystal field splitting of the $3 \mathrm{~d}$ states induced by the first neighbouring shell ligands. The two main peaks, $\mathrm{a}_{2}$ and $\mathrm{b}_{2}$, observed in the absorption spectra of $\mathrm{d}^{0}$ elements, correspond to the $L_{3}$ and $L_{2}$ absorption edges, respectively, and arise from the dipole electron transitions from the spin-orbit split $2 p$ ground states $\left(2 p_{3 / 2}\right.$ and $\left.2 p_{1 / 2}\right)$ to the $3 d$ empty valence states. The weak peaks appearing before the absorption edges are assigned to crystal field splitting that introduces new transitions which are forbidden in highly symmetric environments. Moreover, crystal field splitting affects both the energy position and intensity of the peaks.

To elucidate the contribution of the $\mathrm{Ca}$ atoms occupying the $\mathrm{Ca}_{(1)}$ or $\mathrm{Ca}_{(2)}$ sites in the peaks that appear in the $\mathrm{Ca} L_{2,3}$-edge XANES spectra, the spectrum of HA was simulated using the CTM4XAS code (Fig. 2) which projects the atomic multiplets of $\mathrm{Ca}^{2+}$ to octahedral $\left(\mathrm{O}_{\mathrm{h}}\right)$ and lower $\left(\mathrm{D}_{4 \mathrm{~h}}, \mathrm{C}_{4 \mathrm{v}}\right)$ symmetries taking into account the $2 \mathrm{p}-3 \mathrm{~d}$ spin-orbit coupling and $2 \mathrm{p}-3 \mathrm{~d}$ and $3 \mathrm{~d}-3 \mathrm{~d}$ Coulomb and exchange interactions. In the HA structure, the local symmetry of the $\mathrm{Ca}_{(1)}$ and $\mathrm{Ca}_{(2)}$ site results in different crystal field splitting of the $3 \mathrm{~d}$ states, so that each $\mathrm{Ca}$ site gives rise to specific peaks in the absorption spectrum. The best simulation results for the HA spectrum were obtained for a 0.9 value for the Slater integral reduction of the $2 \mathrm{p} 3 \mathrm{~d}$ Coulomb exchange term, whereas the spectrum peaks were convoluted with Lorentzian and Gaussian functions of $0.1 \mathrm{eV}$ width. Similarly to de Groot et al. (1990) the distorted octahedral geometry around the $\mathrm{Ca}_{(2)}$ site (Fig. 1c) was simulated using an octahedral crystal field $\left(\mathrm{O}_{\mathrm{h}}\right.$ symmetry) with a weak positive splitting of $10 \mathrm{Dq}=0.76 \mathrm{eV}$ which gives rise to the $1,2, a_{1}, a_{2}, b_{1}$ and $b_{2}$ peaks (Fig. 2a). The symmetry of 9-fold coordinated $\mathrm{Ca}_{(1)}$ site (Fig. 1b) breaks to a single $\left(\sigma_{\mathrm{h}}\right)$ mirror plane while the reduced site symmetry can be assessed by further distorting the co-ordination polyhedron around the $\mathrm{Ca}_{(1)}$ site resulting in a tetragonal overall symmetry (Rez and Blackwell 2011). The lower symmetry of the $\mathrm{Ca}_{(1)}$ site was simulated using $\mathrm{D}_{4 \mathrm{~h}}$ symmetry and the respective crystal field splitting in CTM4XAS code is defined by the octahedral (10Dq), tetrahedral (Dt) and square (Ds) crystal field parameters. The best simulation was obtained for $10 \mathrm{Dq}=-0.6 \mathrm{eV}, \mathrm{Dt}=0.06 \mathrm{eV}$ and $\mathrm{Ds}=0 \mathrm{eV}$ and the respective absorption spectrum includes 8 peaks. The two peaks, indicated with an asterisk (Fig. 2a), have very low intensity and are not observed in the HA spectrum while the remaining peaks correspond to the $2, a_{10}, a_{2}, 3, b_{10}$ and $b_{2}$ peaks in the spectrum. Subsequently, the simulated absorption spectra for $\mathrm{O}_{\mathrm{h}}$ and $\mathrm{D}_{4 \mathrm{~h}}$ symmetries were multiplied by 0.6 and 0.4 , respectively, according to the multiplicity of the $\mathrm{Ca}_{(2)}$ and $\mathrm{Ca}_{(1)}$ sites in the HA unit cell and then they were summed up. The resulting simulated spectrum was shifted by $1.72 \mathrm{eV}$ to allow for better comparison with the experimental spectrum of HA as shown in 
Fig. 2b. The peak positions of the simulated spectra of the $\mathrm{O}_{\mathrm{h}}$ and $\mathrm{D}_{4 \mathrm{~h}}$ symmetries, obtained from the $2^{\text {nd }}$ derivative of the corresponding spectra, are listed in Table 1 and are in good agreement with the fitting results of the HA spectrum.

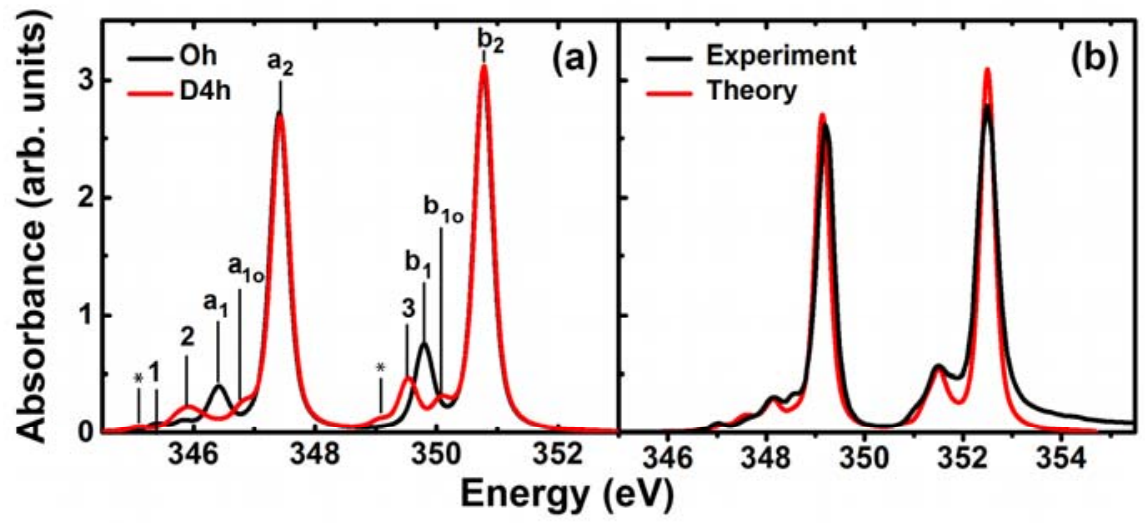

Figure 2. CTM4XAS simulation of the $C a L_{2,3}$-edge XANES spectrum of HA. (a) Simulated contribution in the HA spectrum of the $\mathrm{Ca}_{(1)}$ and $\mathrm{Ca}_{(2)}$ sites with point symmetry $\mathrm{D}_{4 \mathrm{~h}}$ and $\mathrm{O}_{\mathrm{h}}$, respectively, (b) comparison of the simulated and experimental XANES spectra of HA.

Table 1. Ca $L_{2,3}$-edge XANES peak positions obtained after fitting the spectra of the fossil bone specimens and reference samples. The peak positions of the simulated contributions of the $\mathrm{Ca}_{(1)}$ and $\mathrm{Ca}_{(2)}$ sites of the HA with $\mathrm{O}_{\mathrm{h}}$ and $\mathrm{D}_{4 \mathrm{~h}}$ symmetries, respectively, were obtained from the $2^{\text {nd }}$ derivatives of the simulation curves.

\begin{tabular}{|c|c|c|c|c|c|c|c|c|c|c|c|c|c|}
\hline & \multicolumn{13}{|c|}{ Peak positions (eV) } \\
\hline & 1 & 2 & $a_{1}$ & $a_{10}$ & $a_{2}$ & 3 & $\mathrm{~b}_{1}$ & $b_{10}$ & $b_{2}$ & $a_{2}-a_{1}$ & $b_{2}-b_{1}$ & $\mathrm{~b}_{2}-\mathrm{a}_{2}$ & Crys. $^{1}$ \\
\hline \multicolumn{14}{|c|}{ Simulation ${ }^{2}$} \\
\hline $\mathrm{O}_{\mathrm{h}}$ & 347.11 & 347.55 & 348.15 & - & 349.14 & - & 351.52 & - & 352.49 & 0.99 & 0.97 & 3.35 & - \\
\hline $\mathrm{D}_{4 \mathrm{~h}}$ & 346.81 & 347.62 & - & 348.53 & 349.15 & 351.22 & - & 351.82 & 352.50 & - & - & 3.35 & - \\
\hline sample & \multicolumn{13}{|c|}{ Reference samples } \\
\hline Calf fresh bone & - & 347.63 & $347.92 / 348.15$ & 348.57 & 349.21 & 351.31 & 351.47 & 351.77 & 352.50 & 1.06 & 1.03 & 3.29 & - \\
\hline Quebec apatite & 347.05 & 347.70 & 348.18 & 348.61 & 349.24 & 351.16 & 351.49 & 351.81 & 352.50 & 1.06 & 1.01 & 3.26 & 0.845 \\
\hline Durango apatite & 347.03 & 347.64 & 348.15 & 348.58 & 348.20 & 351.08 & 351.49 & 351.87 & 352.50 & 1.11 & 1.05 & 3.28 & 0.835 \\
\hline $\begin{array}{l}\text { Norway } \\
\text { Chlorapatite }\end{array}$ & 347.03 & 347.64 & 348.15 & 348.58 & 349.20 & 351.08 & 351.49 & 351.87 & 352.50 & 1.05 & 1.01 & 3.30 & 0.835 \\
\hline Calcite & 346.90 & 347.43 & 348.02 & - & 349.27 & - & 351.35 & - & 352.60 & 1.25 & 1.25 & 3.33 & - \\
\hline HA & 347.02 & 347.63 & 348.15 & 348.58 & 349.21 & 351.07 & 351.48 & 351.81 & 352.50 & 1.06 & 1.02 & 3.29 & 0.845 \\
\hline \multicolumn{14}{|c|}{ Fossil bone specimens } \\
\hline KR-2 & 347.05 & 347.67 & 348.16 & 348.60 & 349.21 & 351.13 & 351.48 & 351.82 & 352.50 & 1.05 & 1.02 & 3.28 & 0.83 \\
\hline KR-4 & 347.02 & 347.64 & 348.14 & 348.59 & 349.20 & 351.09 & 351.45 & 351.81 & 352.50 & 1.06 & 1.05 & 3.30 & 0.835 \\
\hline KR-6 & 347.02 & 347.68 & 348.17 & 348.60 & 349.21 & 351.13 & 351.47 & 351.82 & 352.50 & 1.04 & 1.03 & 3.29 & 0.825 \\
\hline
\end{tabular}

${ }^{1}$ Crystallinity is defined as the difference of the $a_{2}$ - average $\left(a_{1}, a_{10}\right)$ peak positions.

${ }^{2}$ The energy positions were shifted by $1.72 \mathrm{eV}$ to allow for better comparison with the HA spectrum. 


\section{Optical and Scanning Electron Microscopy}

Prior to the $\mathrm{Ca} L_{2,3}$-edge XANES characterization of fossil specimens, OM and SEM microscopies were used for the investigation of the degree of destruction and chemical alterations in fossil bone apatite as well as for the selection of the most appropriate specimens for Ca $L_{2,3}$-edge XANES measurements. Optical microscopy images reveal that the majority of the samples show excellent histological preservation, absence of microbial attack $(\mathrm{OHI}=5)$, minor cracking and permineralization (precipitation of secondary phases in histological voids) while the KR-2 and KR-4 samples exhibit severe bacterial alteration in the form of non-Wedl microscopical focal destruction (MFD). Table 2 summarizes the histological and chemical alterations observed by OM and SEM microscopies while representative SEM-BSE images of the samples are shown in Fig. 3. The highly recrystallized rims surrounding the MDF tunnels appear brighter (white) in the SEM-BSE images (Fig. 3a) and contain less F content than the remaining bone apatite (grey). The KR-4 sample exhibits increased microbial porosity (Fig. 3b) whereas the diameter of the smaller pores shown in Fig. 3c is $0.5 \pm 0.1 \mu \mathrm{m}$. On the contrary, in the KR-2 sample the largest part of cortical and cancellous bone has been dissolved and replaced by large $\mathrm{CaCO}_{3}$ crystals. The remaining cortical bone is heavily altered by dissolution and bacterial borings (Fig. 3e) while only minor areas of wellpreserved apatite are observed (Fig. 3d). Most of the highly recrystallized rims are empty or filled with $(\mathrm{Mg}, \mathrm{Fe})$-rich $\mathrm{CaCO}_{3}$ precipitations of granular texture (Fig. 3f). Sub-micron microbial porosity is also observed at preserved MFD (Fig. 3f) however the KR-2 sample is mainly characterized by increased dissolution porosity. Figs. $3 \mathrm{~g}$ and $3 \mathrm{~h}$ show representative SEM-BSE images of samples unaffected by bioerosion $(\mathrm{OHI}=5)$. The SEM-EDX spectra revealed that the initial carbonated hydroxyapatite $\mathrm{Ca}_{10}\left(\mathrm{PO}_{4}, \mathrm{CO}_{3}\right)_{6}(\mathrm{OH})_{2}$ of the skeletal remains has been partially transformed to fluorapatite (the degree of substitution ranges from 18 to 96 at\% within the sample) and is enriched in $\mathrm{K}, \mathrm{Na}, \mathrm{Rb}$ and $\mathrm{Sr}$. In the areas of low F content, $\mathrm{Cl}$ was also detected with a $\mathrm{Cl} / \mathrm{F}$ weight ratio ranging from 0.35 to $0.51( \pm 0.03)$. The degree of $\mathrm{Ca}^{2+}$ substitution varied from 0.02 to 0.58 atoms per formula units, while in one sample (KR-2) a small amount of $\mathrm{SO}_{4}{ }^{2-}$ that substitutes for $\mathrm{PO}_{4}{ }^{3-}$ was detected. A summary of the SEM-EDX quantification results is provided in Online Resource 1. Apart from $(\mathrm{Mg}, \mathrm{Fe})$ calcite, $\mathrm{Fe}$ and $\mathrm{Mn}$ oxides as well as $\mathrm{HA}$ aggregations were observed, filling histological voids such as vascular canals and osteocyte lacunae. Detrital mineral phases related to the depositional environment were observed in the cancellous bone areas and include subhedral quartz, tabular microcline, muscovite and biotite in the form of leaves and tablets, foliated chlorite, anhedral prismatic epidote, subhedral to anhedral oligoclase and tabular albite. Anhedral calcite precipitation was observed in remaining spaces available. 

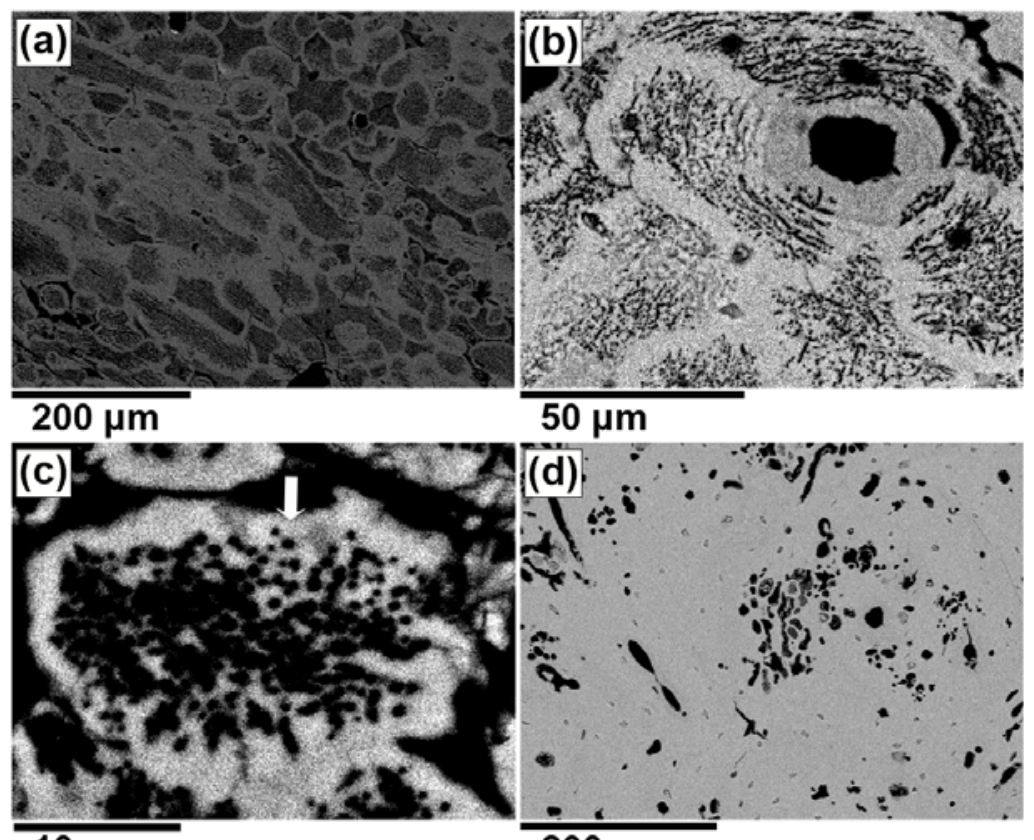

$50 \mu \mathrm{m}$
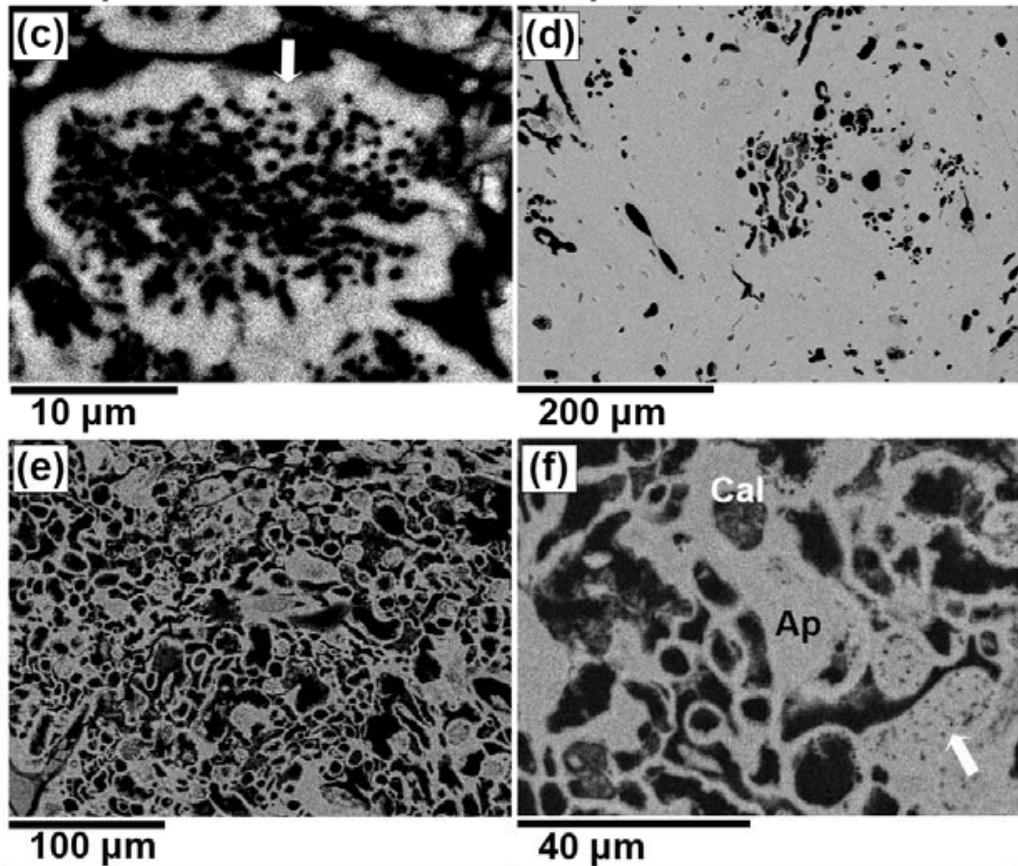

$200 \mu \mathrm{m}$

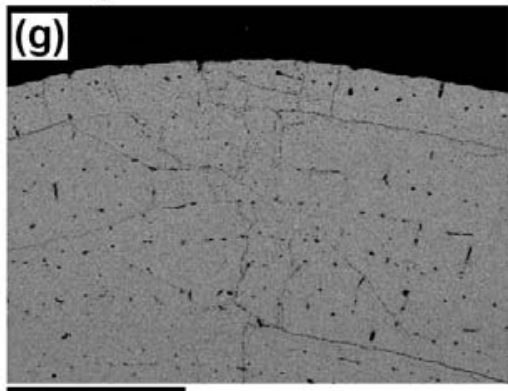

$1 \mathrm{~mm}$

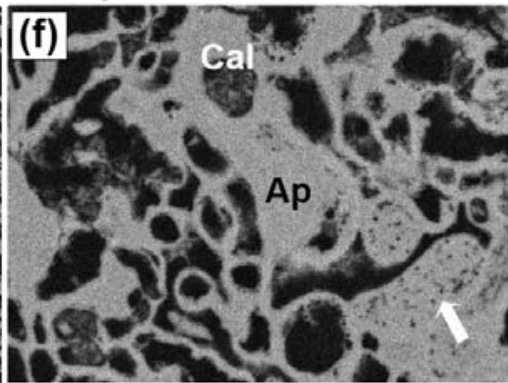

$40 \mu \mathrm{m}$

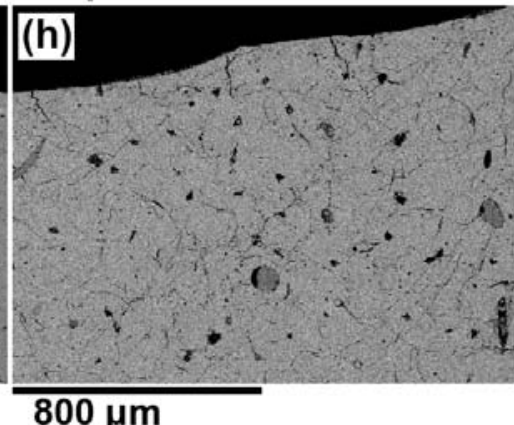

Figure 3. Representative SEM-BSE images of samples with varying degree of histological preservation. (a) Non-Wedl MFD in the compacta of the KR-4 bone, (b) increased microbial porosity in a secondary osteon of the KR-4 bone, (c) submicron bacterial borings, indicated by an arrow, in the KR-4 sample, (d) area of preserved apatite in the KR-2 compacta, (e) generalized destruction and increased dissolution porosity in the KR-2 bone, (f) microbial borings, indicated by an arrow, and calcite (precipitation in the MFD of the KR-2 bone, (g) well-preserved compacta of the KR-6 bone, (h) endosteum area of the KR-9 bone showing extended cracking. Notation: Cal: Calcium carbonate; Ap: Apatite 
Table 2. Histological characterization of fossil bone specimens and minerals detected in cortical bone voids (CB), medullar cavity (MC) and endosteum surface (ES) by means of Optical and Scanning Electron Microscopies. OHI stands for the Oxford Histological Index.

\begin{tabular}{|c|c|c|c|}
\hline Specimen & OHI & Erosion features & Minerals detected in histological voids \\
\hline KR-1 & 5 & $\begin{array}{l}\text { enlarged osteocyte lacunae, minor } \\
\text { dissolution, micro-cracking, minor } \\
\text { large cracks (thickness }>40 \mu \mathrm{m} \text { ), } \\
\text { permineralization }\end{array}$ & $\begin{array}{l}\text { CB: calcite } \\
\text { MC: calcite, quartz, albite, biotite, muscovite, chlorite, epidote, oligoclase, } \\
\text { microcline, Mn oxides }\end{array}$ \\
\hline KR-2 & 1 & $\begin{array}{l}\text { extended dissolution, non-Wedl MFD, } \\
\text { permineralization }\end{array}$ & $\begin{array}{l}\text { CB: calcite, hydroxyapatite } \\
\text { MC: calcite, quartz, albite, biotite, muscovite, chlorite, epidote, oligoclase, } \\
\text { microcline }\end{array}$ \\
\hline KR-3 & 5 & $\begin{array}{l}\text { minor dissolution, micro-cracking, } \\
\text { permineralization }\end{array}$ & CB: calcite, hydroxyapatite \\
\hline KR-4 & 0 & $\begin{array}{l}\text { minor dissolution, non Wedl MFD, } \\
\text { minor large cracks, permin eraliztion }\end{array}$ & CB: Mn oxides, pyrite \\
\hline KR-5 & 5 & $\begin{array}{l}\text { micro-cracking, minor large cracks, } \\
\text { permineralization }\end{array}$ & $\begin{array}{l}\text { CB: calcite, hydroxyapatite } \\
\text { MC: calcite, quartz, albite, biotite, muscovite, chlorite, epidote, oligoclase, } \\
\text { microcline }\end{array}$ \\
\hline KR-6 & 5 & $\begin{array}{l}\text { minor micro-cracking, } \\
\text { permineralization }\end{array}$ & CB: calcite, Mn oxides, hydroxyapatite \\
\hline KR-7 & 5 & $\begin{array}{l}\text { minor dissolution, mi cro-cracking, } \\
\text { minor large cracks, permin eralization }\end{array}$ & $\begin{array}{l}\text { CB: calcite, hydroxyapatite } \\
\text { MC:calcite }\end{array}$ \\
\hline KR-8 & 5 & micro-cracking, permineralization & CB:calcite, hydroxyapatite \\
\hline KR-9 & 5 & $\begin{array}{l}\text { extended cracking, minor large cracks, } \\
\text { permineralization }\end{array}$ & $\begin{array}{l}\text { CB:calcite, Mn oxides, Fe oxides, hydroxyapatite } \\
\text { ES: calcite, quartz, Mn oxides, albite, muscovite, chlorite, epidote }\end{array}$ \\
\hline
\end{tabular}

\section{Ca $L_{2,3}$-edge XANES spectroscopy}

The Ca $L_{2,3}$-edge XANES spectra of the KR-2, KR-4, KR-6 powdered bone specimens, reference HA, Quebec apatite, Durango apatite, Chlorapatite Norway, and fresh calf bone samples are shown in Fig. 4. The spectra were fitted using Voigt and Sigmoidal lineshapes and the fitting results are listed in Table 1. The HA spectrum, and the spectra of the fossil bone specimens, were fitted using 9 peaks labelled as $1,2, \mathrm{a}_{1}, \mathrm{a}_{1 \mathrm{o}}, \mathrm{a}_{2}\left(L_{3}\right) 3, \mathrm{~b}_{1}, \mathrm{~b}_{1 \mathrm{o}}$ and $\mathrm{b}_{2}\left(L_{2}\right)$ according to the notation of de Groot et al. (1990).

The fitting analysis reveals that the peak positions of both bacterially attacked (KR-4, KR-2) and well-preserved bone (KR-6) have intermediate values between the reference spectra of HA and geological Quebec apatite while small variations in the $\left(a_{2}-a_{1}\right)$ and $\left(b_{2}-b_{1}\right)$ peak separations are also observed. Moreover, the energy difference between the $a_{2}$ and " $a_{1}$ " peaks is used as a measure of the order in the apatite crystals (that will be designated hereafter as crystallinity) according to Beniash et al. (2009). However, in their study the $\mathrm{a}_{1}$ and $\mathrm{a}_{1 \mathrm{o}}$ peaks were not discriminated and were considered together as a broad peak. In our analysis, in order to obtain crystallinity values, we subtract the average position of $\mathrm{a}_{1}$, $\mathrm{a}_{1 \mathrm{o}}$ peaks from the position of the $\mathrm{a}_{2}$ peak. The highly mineralized, due to extensive microbial attack, KR-4 sample shows the highest crystallinity which is comparable to geologic Durango and Norway apatites, however, it is lower than stoichiometric HA. The KR-2 sample that was subjected to extensive microbial attack and 
catastrophic mineral dissolution exhibits lower crystallinity than the KR-4 sample while the lowest value was observed for the well-preserved KR-6 sample. Apart from HA, no secondary calcium phosphate minerals are present in the fossil samples, as it is deduced from the $\mathrm{P} L_{2,3}$-edge spectra of KR-2 and KR-4 samples (Online Resource 2). The features observed in the P $L_{2,3}$-edge spectra such as the spin-orbit doublet, peaks (a) and (b), white line, (c), and shoulders, (d) and (e) are typical of calcium phosphate minerals and are consistent with the HA reference spectrum. The peak energy positions and relative intensity ratios are listed in Online Resource 3 . Finally, in the $\mathrm{Ca} L_{2,3}$-edge XANES spectrum of the calf fresh bone sample, increased full widths at half maximum (FWHM) are observed for the $a_{1}$ and $b_{1}$ peaks compared to the HA spectrum.

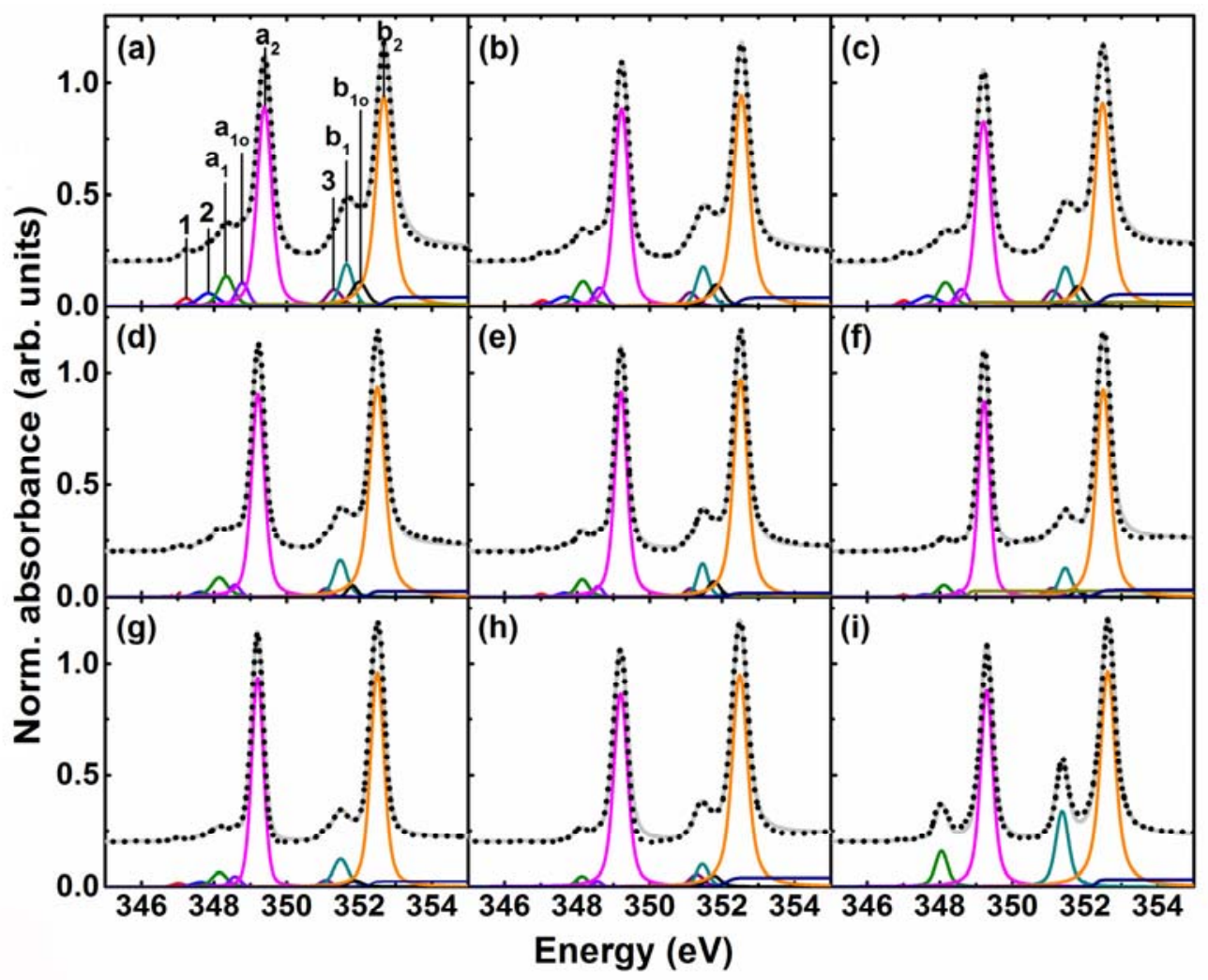

Figure 4. $\mathrm{Ca} L_{2,3}$-edge XANES spectra and corresponding fitting of the: (a) KR-2 sample, (b) KR-4 sample, (c) KR-6 sample, (d) HA, (e) Quebec apatite, (f) Durango apatite, (g) Chlorapatite Norway, (h) Fresh bone calf, (i) Calcite. The experimental spectra (black dots) and fitting curves (grey lines) have been shifted along the y-axis for clarity.

\section{Sr K-edge EXAFS}

Sr K-edge EXAFS spectroscopy was used to study the bonding environment of $\mathrm{Sr}$ in the periosteum area of eight fossil samples with varying $\mathrm{Sr}$ concentration. The fitting of the EXAFS spectra in the k- and R-space is shown in Fig. 5. The fitting results, along with the theoretical nearest neighbour distances of $\mathrm{Ca}$ in the HA and fluorapatite (FAp) model and the $\mathrm{Sr} / \mathrm{Ca}$ weight ratios as determined by the XRF spectra are listed in Table 3. The Sr-O bondlength in the first neighbouring shell (NS) remains unaltered, irrespectively of the $\mathrm{Sr}$ 
content and lies close to the corresponding value in the FAp model, whereas the average distances in the next NS are higher than the respective in the HA and FAp models and range between 3.20 and 3.25 $\AA$. In the third coordination shell the Sr-Ca interatomic distance is larger compared to the FAp model and its average value is $3.50 \AA$ for all samples except for the sample with the highest $\mathrm{Sr}$ content in which the $\mathrm{Sr}-\mathrm{Ca}$ bond is equal to the respective in the HA model. On the contrary, the average Sr-Ca distance in the fourth NS increases with $\mathrm{Sr}$ content in respect to the HA and FAp structures while its values range from $4.08 \AA$ (for low $\mathrm{Sr}$ content) to $4.13 \AA$ (for high $\mathrm{Sr}$ content). The average Sr-O distance in the fifth NS is similar to the HA and FAp models whereas the average Sr-O distance in the sixth NS ranges between 4.84 and $4.95 \AA$. Finally, samples with $\mathrm{Sr} / \mathrm{Ca}<0.012$ show increased static disorder beyond the fourth coordination shell, as it can be deduced from the higher Debye-Waller factors.
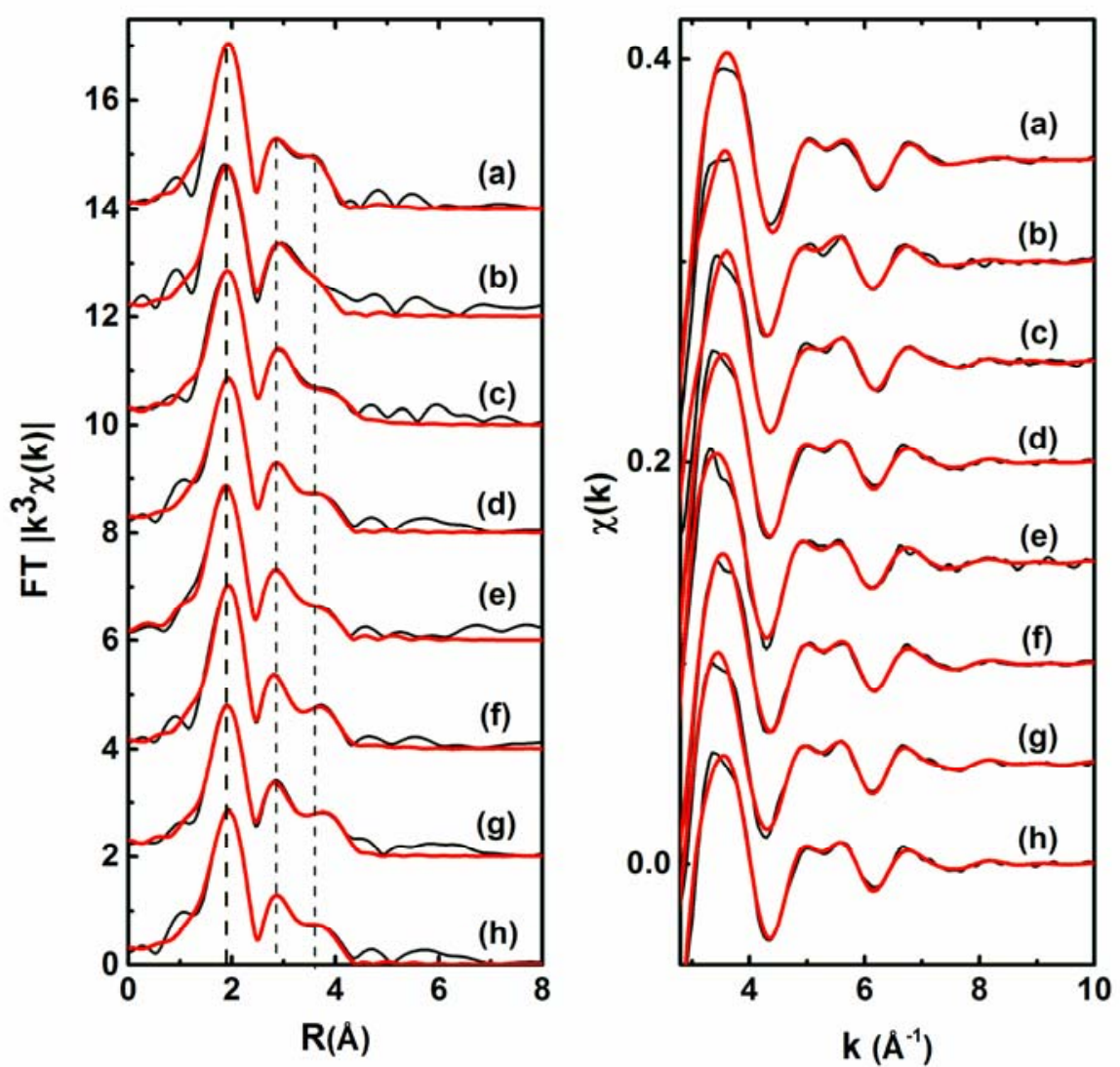

Fig. 5 Sr K-edge $\chi(k)$ and corresponding Fourier Transforms of the: (a) KR-5, (b) KR-3, (c) KR-8, (d) KR-9 white, (e) KR-2, (f) KR-9 black, (g) KR-4 and (h) KR-6 samples. The spectra are presented in order of increasing $\mathrm{Sr} / \mathrm{Ca}(\mathrm{gr} / \mathrm{gr})$ ratio. The experimental and fitting curves are shown in black (thin) and red (thick) lines, respectively 
Table 3. Fitting results of Sr K-edge EXAFS spectra. N, R in $\AA$, and $\sigma^{2}$ in $\AA^{2}$, stand for the coordination number that was kept fixed according to the model of HA, the nearest neighbor distance and the Debye-Waller factor. The nearest neighbor distances that correspond to the reference HA and FAp samples are also listed. The quoted errors correspond to the uncertainties provided by the FEFFIT software. The $\mathrm{Sr} / \mathrm{Ca}$ weight ratio values were determined from the XRF spectra.

\begin{tabular}{|c|c|c|c|c|c|c|c|c|}
\hline \multirow[t]{2}{*}{1} & & \multirow{2}{*}{$\begin{array}{l}\text { Para- } \\
\text { meters }\end{array}$} & \multicolumn{6}{|c|}{ Nearest Neighb our Shells } \\
\hline & & & NS1:O & $N S 2: \mathrm{P}$ & NS3:Ca & NS4:Ca & NS5:0 & NS6:0 \\
\hline Sample & $\mathrm{Sr} / \mathrm{Ca}$ & $\mathrm{N}$ & 8.4 & 2.4 & 0.8 & 8.4 & 4.8 & 6.5 \\
\hline \multirow{2}{*}{ KR-5 } & \multirow{2}{*}{0.008} & $\mathrm{R}$ & $2.53 \pm 0.01$ & $3.22 \pm 0.02$ & $3.53 \pm 0.03$ & $4.09 \pm 0.03$ & $4.39 \pm 0.03$ & $4.93 \pm 0.04$ \\
\hline & & $\sigma^{2}$ & $0.017 \pm 0.001$ & $0.015 \pm 0.002$ & $0.013 \pm 0.002$ & $0.021 \pm 0.003$ & $0.037 \pm 0.004$ & $0.030 \pm 0.003$ \\
\hline \multirow{2}{*}{ KR-3 } & \multirow{2}{*}{0.011} & R & $2.51 \pm 0.02$ & $3.25 \pm 0.02$ & $3.49 \pm 0.02$ & $4.10 \pm 0.03$ & $4.39 \pm 0.02$ & $4.84 \pm 0.05$ \\
\hline & & $\sigma^{2}$ & $0.017 \pm 0.001$ & $0.015 \pm 0.009$ & $0.005 \pm 0.001$ & $0.022 \pm 0.004$ & $0.021 \pm 0.008$ & $0.055 \pm 0.017$ \\
\hline \multirow{2}{*}{ KR-8 } & \multirow{2}{*}{0.012} & $\mathbf{R}$ & $2.50 \pm 0.01$ & $3.22 \pm 0.02$ & $3.50 \pm 0.02$ & $4.09 \pm 0.02$ & $4.47 \pm 0.03$ & $4.84 \pm 0.04$ \\
\hline & & $\sigma^{2}$ & $0.015 \pm 0.002$ & $0.015 \pm 0.002$ & $0,006 \pm 0.002$ & $0.026 \pm 0.004$ & $0,007 \pm 0,001$ & $0.014 \pm 0.007$ \\
\hline \multirow{2}{*}{$\begin{array}{l}\text { KR-9 } \\
\text { (white) }\end{array}$} & \multirow{2}{*}{0.013} & $\bar{R}$ & $2.50 \pm 0.01$ & $3.20 \pm 0.02$ & $3.54 \pm 0.02$ & $4.07 \pm 0.02$ & $4.43 \pm 0.02$ & $4.89 \pm 0.03$ \\
\hline & & $\sigma^{2}$ & $0.017 \pm 0.001$ & $0.020 \pm 0.001$ & $0.007 \pm 0.001$ & $0.032 \pm 0.003$ & $0.010 \pm 0.001$ & $0.022 \pm 0.007$ \\
\hline \multirow{2}{*}{ KR-2 } & \multirow{2}{*}{0.017} & $\mathbf{R}$ & $2.53 \pm 0.01$ & $3.23 \pm 0.01$ & $3.50 \pm 0.02$ & $4.13 \pm 0.03$ & $4.40 \pm 0.04$ & $5.03 \pm 0.08$ \\
\hline & & $\sigma^{2}$ & $0.016 \pm 0.001$ & $0.016 \pm 0.001$ & $0,006 \pm 0,002$ & $0,028 \pm 0,005$ & $0,011 \pm 0,004$ & $0.028 \pm 0.009$ \\
\hline \multirow{2}{*}{$\begin{array}{l}\text { KR-9 } \\
\text { (black) }\end{array}$} & \multirow{2}{*}{0.020} & $\mathbf{R}$ & $2.53 \pm 0.01$ & $3.22 \pm 0.01$ & $3.49 \pm 0.02$ & $4.12 \pm 0.03$ & $4.39 \pm 0.03$ & $4.95 \pm 0.05$ \\
\hline & & $\sigma^{2}$ & $0.015 \pm 0.002$ & $0.012 \pm 0.002$ & $0.010 \pm 0.002$ & $0.022 \pm 0.004$ & $0.025 \pm 0.004$ & $0.015 \pm 0.005$ \\
\hline \multirow{2}{*}{ KR-4 } & \multirow{2}{*}{0.024} & $\mathrm{R}$ & $2.52 \pm 0.01$ & $3.22 \pm 0.01$ & $3.52 \pm 0.02$ & $4.14 \pm 0.03$ & $4.39 \pm 0.03$ & $4.92 \pm 0.04$ \\
\hline & & $\sigma^{2}$ & $0.014 \pm 0.002$ & $0.014 \pm 0.002$ & $0.006 \pm 0.001$ & $0.022 \pm 0.003$ & $0.006 \pm 0.002$ & $0.010 \pm 0.004$ \\
\hline \multirow{2}{*}{ KR-6 } & \multirow{2}{*}{0.040} & R & $2.52 \pm 0.01$ & $3.23 \pm 0.01$ & $3.46 \pm 0.02$ & $4.12 \pm 0.03$ & $4.43 \pm 0.03$ & $4.93 \pm 0.05$ \\
\hline & & $\sigma^{2}$ & $0.018 \pm 0.002$ & $0.013 \pm 0.002$ & $0.013 \pm 0.002$ & $0.027 \pm 0.003$ & $0.014 \pm 0.002$ & $0.027 \pm 0.003$ \\
\hline HA & - & $\mathrm{R}$ & 2.44 & 3.11 & 3.46 & 3.95 & 4.45 & 4.69 \\
\hline FAp & - & $\mathbf{R}$ & 2.51 & 3.19 & 3.44 & 4.03 & 4.44 & 4.8 \\
\hline
\end{tabular}




\section{Discussion}

\section{CTM4XAS simulation of the $C a L_{2,3}$-edge XANES spectrum of HA}

In order to get insight on the origin of the multi-peak pattern observed in the Ca $L_{2,3}$-edge spectrum of the reference HA, it was simulated with the CTM4XAS software as a sum of two atomic multiplet spectra arising from the different local symmetry of the two non-equivalent $\mathrm{Ca}$ sites in the HA lattice. The $\mathrm{Ca}^{2+}$ multiplets of the $\mathrm{Ca}_{(2)}$ site were projected in $\mathrm{O}_{\mathrm{h}}$ symmetry using a positive crystal field $(10 \mathrm{Dq}=0.76 \mathrm{eV})$ which gave rise to the $1,2, \mathrm{a}_{1}, \mathrm{a}_{2}, \mathrm{~b}_{1}$ and $\mathrm{b}_{2}$ peaks in the HA spectrum while the $\mathrm{Ca}_{(1)}$ site geometry was simulated with a $\mathrm{D}_{4 \mathrm{~h}}$ symmetry with an octahedral crystal parameter of $10 \mathrm{Dq}=-0.6 \mathrm{eV}$ and a tetrahedral crystal field parameter of $\mathrm{Dt}=0.06 \mathrm{eV}$. The $\mathrm{Ca}_{(1)}$ site gives rise to the $\mathrm{a}_{10}, 3$ and $\mathrm{b}_{1 \mathrm{o}}$ peaks and contributes to the intensity of the $2, a_{2}, b_{2}$ peaks of the HA spectrum. In order to account for the multiplicity of the $\mathrm{Ca}_{(2)}$ and $\mathrm{Ca}_{(1)}$ sites in the HA unit cell, the simulated multiplet spectra in $\mathrm{O}_{\mathrm{h}}$ and $\mathrm{D}_{4 \mathrm{~h}}$ symmetries were multiplied by 0.6 and 0.4 , respectively, and were subsequently summed. The good agreement of the peak positions of the calculated $\mathrm{Ca}^{2+}$ spectra in $\mathrm{O}_{\mathrm{h}}$ and $\mathrm{D}_{4 \mathrm{~h}}$ symmetries with respect to the fitting results of the HA spectrum, as well as the overall agreement of the summed multiplet spectrum in comparison to the experimental HA spectrum reveals that the features observed in the HA spectrum arise from the different site symmetry of the $\mathrm{Ca}_{(1)}$ and $\mathrm{Ca}_{(2)}$ sites. These results are also in agreement with Fleet and Liu (2009) who proposed that the $\mathrm{Ca}_{(2)}$ site in carbonated HA is associated with a positive $10 \mathrm{Dq}$ while the $\mathrm{Ca}_{(1)}$ site experiences a weak crystal field and negative 10Dq. The peak 3 has not been observed in the Ca $L_{2,3}$-edge spectra of HA published previously (Benzerara et al. 2004; Fleet and Liu 2009). However, these studies do not include detailed analysis of the spectra. This shoulder peak is necessary, particularly for the fitting of fossil bone samples while the simulation results suggest that it is related to the symmetry of the $\mathrm{Ca}_{(1)}$ site (Zougrou et al. 2016).

\section{Microscopical analysis of fossil bones}

The fossilization-induced morphological and chemical alterations in nine fossil bone specimens from the Kryopigi locality were assessed by optical and scanning electron microscopies. The majority of the samples is characterized by excellent histological preservation, absence of bioerosion $(\mathrm{OHI}=5)$ and minor erosion features while the KR-2 and KR-4 specimens exhibit extremely poor histological preservation ( $\mathrm{OHI}=1$ and 0 respectively) due to extensive non-Wedl bacterial alterations. The KR-2 sample is also characterized by catastrophic mineral dissolution. The extensive bone dissolution observed in the KR-2 sample, also enhanced by microbial porosity, reveals that the specimen was subjected to a continuous water flow (Millard and Hedges 1995). The absence of similar diagenetic changes in the remaining specimens, indicates that the KR-2 sample was preserved in coarse-grained sediment and thus it was subjected to increased groundwater interaction. SEM-EDX analysis 
revealed that the fossil bone apatite has been partially transformed to fluorapatite and is enriched in $\mathrm{K}, \mathrm{Na}, \mathrm{Rb}$ and $\mathrm{Sr}$. Furthermore, deposition of quartz, epidote, albite, oligoclase, biotite, muscovite and chlorite as well as precipitation of anhedral late-diagenetic calcite was observed in the medullar cavities of the samples. This assemblage of environment-related minerals is characteristic of metamorphism at low temperatures and pressures and reveals the slightly acidic $\mathrm{pH}$ conditions of the deposition sediments. Although bone apatite solubility is known to increase with decreasing $\mathrm{pH}$, the vast precipitation of calcite during late diagenesis may indicate saturation of the solution with respect to calcite which in turn prevents carbonated apatite from dissolving (Berna et al. 2004). Moreover, the large size of the $\mathrm{CaCO}_{3}$ crystals observed in diagenetic cracks or histological voids implies crystallization under constant temperature and pressure for a long period of time during the late stage of diagenesis while the presence of Fe, Mn oxides in vascular canals and osteocyte lacunae indicates late oxidising conditions.

\section{Ca bonding and apatite crystallinity of fossil bone}

Ca $L_{2,3}$-edge XANES spectroscopy was used to characterize the chemical composition and electronic states of bacterially attacked and well-preserved fossil bones as well as of fresh bone. The fitting results of the $\mathrm{Ca}_{2,3}$-edge XANES spectra of fossil bone specimens show that the peak positions have intermediate values in between those of the reference HA and geological Quebec apatite. The crystal field arising from the coordination of atoms in the first neighbouring shell of $\mathrm{Ca}^{2+}$ affects the position and the intensity of the peaks in the spectrum (de Groot et al. 1990), thus the slight violet shift observed in the peak positions of the bone samples with respect to HA can be attributed to the effect of ionic substitutions in the lattice. This effect is also evident in the variations in the $\left(a_{2}-a_{1}\right)$ and $\left(b_{2}-b_{1}\right)$ peak separations which are non-linearly related to the crystal field parameter 10Dq (de Groot et al. 1990). Concerning the Ca $L_{2,3}$-edge XANES spectrum of the calf fresh bone sample, the increased peak widths (FWHM) of the $a_{1}$ and $b_{1}$ peaks reveal a higher degree of disorder, indicating an increased $\mathrm{CO}_{3}{ }^{2-}$ content, smaller crystal size and/or the presence of other Ca-phosphate phases.

The characteristics of the Ca $L_{2,3}$-edge XANES spectra were used for the assessment of the crystallinity in three types of fossil bone: a) heavily bacterially attacked bone with increased m-porosity (KR-4), (b) heavily bacterially altered bone with catastrophic mineral dissolution or increased 1-porosity (KR-2), (c) histologically well-preserved bone (KR-6). The highest (lowest) crystallinity value was observed for the KR-4 (KR-6) sample. This observation contrasts the findings of Smith et al. (2007) who although observed an increase in crystallinity with the amount of microbial attack in bioeroded bones, reported that bones without signs of bioerosion exhibit the highest crystallinity values. The higher crystallinity values observed in bacterially attacked bone in our study, suggest that bioerosion influences the crystallization process presumably via its by-products. Further investigation for the clarification of the role of bioerosion in apatite crystallinity needs to be undertaken. Moreover, phosphate solubilizing bacteria have been extensively studied for agriculture 
improvement (i.e. Rodríguez and Fraga 1999) however their role in bone recrystallization still needs to be elucidated.

\section{Sr incorporation in fossil bone apatite}

The local bonding environment of $\mathrm{Sr}$ and the $\mathrm{Ca}$ site preference with varying $\mathrm{Sr} / \mathrm{Ca}$ content was assessed by $\mathrm{Sr} K$-edge EXAFS spectra. The $\mathrm{Sr} / \mathrm{Ca}$ weight ratio that ranged from 0.008 to $0.024 \mathrm{gr} / \mathrm{gr}$ in the examined fossil specimens, corresponds to a range of approximately 0.04$0.18 \mathrm{Sr}$ atoms per formula unit (apfu) in $\mathrm{Ca}_{10-\mathrm{x}} \mathrm{Sr}_{\mathrm{x}}\left(\mathrm{PO}_{4}\right)_{6}(\mathrm{OH})_{2}$, and contributes to the understanding of the lower end of the HA - Sr-HA solid solution series. The fitting results reveal that $\mathrm{Sr}$ substitution induced an increase in the nearest neighbour distances of all neighbouring shells revealing the increase in the lattice parameters of Sr-HA. More specifically, the average Sr-O bondlength of the first coordination shell is not significantly different from the $\mathrm{Ca}-\mathrm{O}$ bondlength in the fluorapatite model, irrespective of Sr content. This result is in agreement with previous publications on Sr-HA of higher Sr content (Hughes et al. 1990; Rakovan and Hughes 2000). Differences of the order of $0.01 \AA$ in the average Sr-O bond length in the first NS are attributed to structural disorder originating mainly from the distortion of the $\mathrm{Ca}_{(2)}$ polyhedron which contains the $\mathrm{OH}^{-}$ion. Due to the varying degree of fluorination, equivalent differences are observed in the $\mathrm{Sr}-\mathrm{O}$ distances in the fifth and sixth NS. Contrary to Terra et al. (2008) who did not observe changes in the Sr-P and Sr-Ca distances of the second and third NS in low Sr content HA (0.08 Sr apfu) with respect to the HA model, our fitting results reveal that $\mathrm{Sr}$ substitution increases the bond length in the second NS to values comparable to the fluorapatite model while a small increase in the bond length of the third NS is also observed. A further increase is observed in the average Sr-Ca and Sr-O distances of the fourth and sixth NS which are higher than the respective in the HA and FAp models. The Sr-O distance of the fifth $N S$ is approximately the same in the HA and FAp models as well as in the bone Sr-HA.

Finally, if there is a preference for Ca site in this range of $\mathrm{Sr} / \mathrm{Ca}$ ratios, it should be observed in the bonding environment in the third and fourth NS. More specifically, the $3^{\text {rd }}$ coordination shell is related to $\mathrm{Ca}$ atoms of the $\mathrm{Ca}_{(1)}$ polyhedron (Harries et al. 1986). The increased average $\mathrm{Sr}-\mathrm{Ca}$ distance in the third NS reveals that $\mathrm{Sr}$ substitution in the $\mathrm{Ca}_{(1)}$ site takes place for $\mathrm{Sr} / \mathrm{Ca}=0.008-0.024 \mathrm{gr} / \mathrm{gr}$ whereas for higher $\mathrm{Sr}$ content $(\mathrm{Sr} / \mathrm{Ca}=0.040)$ the $\mathrm{Sr}-\mathrm{Ca}$ bond is equal to the respective $\mathrm{Ca}-\mathrm{Ca}$ distance in the HA model indicating that the $\mathrm{Ca}_{(1)}$ site is no longer preferred. On the contrary, the $\mathrm{Ca}$ atoms in the fourth $N S$ are related to both the $\mathrm{Ca}_{(1)}$ and the $\mathrm{Ca}_{(2)}$ sites of the apatite unit cell. According to the Sr-HA model, 2.4 Ca atoms of the $\mathrm{Ca}_{(1)}$ site at distances ranging between 4.00 and $4.09 \AA$ and $6 \mathrm{Ca}$ atoms in the $\mathrm{Ca}_{(2)}$ site at distances ranging between 3.97 and $4.12 \AA$ contribute to the amplitude of the fourth NS. The fitting parameters of the fourth NS indicate $\mathrm{Sr}$ substitution in both the $\mathrm{Ca}_{(1)}$ and $\mathrm{Ca}_{(2)}$ sites, however the bonding distances of high Sr content spectra (4.13 $\AA$ ) advise a preference for the $\mathrm{Ca}_{(2)}$ site. It should be pointed out that the slight variations in the average coordination numbers related to the occupancy of the two sites would affect slightly the Debye-Waller 
factors and not the nearest neighbor distances. Contrary to Bigi et al. (2007) who reported a small preference for the $\mathrm{Ca}_{1}$ site for $0.3 \mathrm{Sr}$ apfu and a preference for the $\mathrm{Ca}_{2}$ site for $0.7 \mathrm{Sr}$ apfu, our analysis reveals a mixed $\mathrm{Ca}_{1}$ and $\mathrm{Ca}_{2}$ occupancy of the $\mathrm{Ca}$ sites with a small preference for the $\mathrm{Ca}_{2}$ site for $\mathrm{Sr} / \mathrm{Ca}=0.017-0.024 \mathrm{gr} / \mathrm{gr}$ (approximately 0.08-0.11 apfu) and a clear preference for the $\mathrm{Ca}_{2}$ site for $\mathrm{Sr} / \mathrm{Ca}=0.040 \mathrm{gr} / \mathrm{gr}$ (approximately $0.18 \mathrm{apfu}$ ).

\section{Conclusions}

Understanding the origin of the multi-peak pattern of the $\mathrm{Ca} L_{2,3}$-edge XANES spectrum of HA is of critical importance to biological, archaeological and palaeontological studies. The CTM4XAS simulation presented here paves the way for a better understanding of the local bonding environment of $\mathrm{Ca}$ in vertebrate bone tissues. The multi-analytical approach of fossil bone apatite provided valuable information on the late diagenetic conditions of the Kryopigi specimens, the nanostructure and site preference of $\mathrm{Sr}$ in biological apatite as well as on the effect of fossilization-induced processes, such as chemical alteration of bone apatite and bioerosion, to the $\mathrm{Ca}_{2,3}$-edge XANES peak pattern and the crystallinity of bone apatite. The possible causal relation between the byproducts of bioerosion and the crystallinity of bioapatite deserves further investigation.

\section{Acknowledgements}

We thank HZB for the allocation of the synchrotron radiation beamtime. The measurements at the storage ring BESSY II of the Helmholtz Zentrum Berlin (HZB) and at HASYLAB were financially supported from the European Community's Seventh Framework Program (FP7/2007-2013) under grant agreements n. ${ }^{\circ} 312284$ and 226716. We would like to deeply thank Dmitry Smirnov for support at the RGBL beamline. We are grateful to Dr. S. Stoulos for providing the geological apatite samples.

\section{References}

Ankudinov AL, Ravel B, Rehr JJ, Conradson SD (1998) Real-space multiple-scattering calculation and interpretation of x-ray-absorption near-edge structure. Phys Rev B 58:7565-7576. doi: 10.1103/PhysRevB.58.7565

Bartsiokas A, Middleton AP (1992) Characterization and Dating of Recent and Fossil Bone by XRay Diffraction. J Archaeol Sci 19:63-72. doi: 10.1016/0305-4403(92)90007-P

Berna F, Matthews A, Weiner S (2004) Solubilities of bone mineral from archaeological sites: the recrystallization window. J Archaeol Sci 31:867-882. doi: 10.1016/j.jas.2003.12.003

Beniash E, Metzler RA, Lam RSK, Gilbert PUPA (2009) Transient amorphous calcium phosphate in forming enamel. J Struct Biol 166:133-143. doi: 10.1016/j.jsb.2009.02.001 
Benzerara K, Yoon TH, Tyliszczak T, Constanz B, Spormann AM, Brown Jr GE (2004) Scanning transmission X-ray microscopy study of microbial calcification. Geobiology 2:249-259. doi: 10.1111/j.1472-4677.2004.00039.x

Bigi A, Boanini E, Capuccini C, Gazzano M (2007) Strontium-substituted hydroxyapatite nanocrystals. Inorg Chim Acta 360:1009-1016. doi: 10.1016/j.ica.2006.07.074

Collins MJ, Nielsen-Marsh CM, Hiller J, Smith CI, Roberts JP, Prigodich RV, Wess TJ, Csapò J, Millard AR, Turner-Walker G (2002) The survival of organic matter in bone: a review. Archaeometry 44:383-394. doi: 10.1111/1475-4754.t01-1-00071

Davis PG (1997) The Bioerosion of Bird Bones. Int Journal Osteoarchaeol 7:388-401. doi: 10.1002/(SICI)1099-1212(199707/08)7:4<388::AID-OA357>3.0.CO;2-H

De Groot FMF, Fuggle JC, Thole BT, Sawatzky GA (1990) $\mathrm{L}_{3,2}$ x-ray-absorption edges of $\mathrm{d}^{0}$ compounds: $\mathrm{K}^{+}, \mathrm{Ca}^{2+}, \mathrm{Sc}^{3+}$, and $\mathrm{Ti}^{4+}$ in $\mathrm{O}_{\mathrm{h}}$ (octahedral) symmetry. Phys Rev B 41:928-937. doi: 10.1103/PhysRevB.41.928

Dumont M, Kostka A, Sander PM, Borbely A, Kaysser-Pyzalla A (2011) Size and size distribution of apatite crystals in sauropod fossil bones. Palaeogeogr Palaeoclimatol Palaeoecol 310:108-116. doi: 10.1016/j.palaeo.2011.06.021

Fleet ME, Liu X (2009) Calcium $\mathrm{L}_{2,3}$-edge XANES of carbonates, carbonate apatite, and oldhamite (CaS). Am Mineral, 94:1235-1241. doi: 10.2138/am.2009.3228

Hackett CJ (1981) Microscopical Focal Destruction (Tunnels) in Exhumed Human Bones. Med Sci Law 21:243-265. doi: 10.1177/002580248102100403

Harries JE, Hukins DWL, Hasnain SS (1986) Analysis of the EXAFS spectrum of hydroxyapatite. J Phys C Solid State 19:6859-6872. doi: 10.1088/0022-3719/19/34/022

Hedges REM (2002) Bone diagenesis: an overview of processes. Archaeometry 4:319-328. doi: $10.1111 / 1475-4754.00064$

Hedges REM, Millard AR, Pike AWG (1995) Measurements and Relationships of Diagenetic Alteration of Bone from Three Archaeological Sites. J Archaeol Sci 22:201-209. doi: 10.1006/jasc. 1995.0022

Hughes JM, Cameron M, Crowley KD (1989) Structural variations in natural F, OH, and Cl apatites. Am Mineral, 74:870-876. 
Jans MME (2008) Microbial bioerosion of bone - a review. In: Wisshak M, Tapanila L (ed) Current Developments in Bioerosion. Springer, Berlin, pp 397-413. doi: 10.1007/978-3-54077598-0_20

Keenan SW, Engel AS, Roy A, Bovenkamp-Langlois GL (2015) Evaluating the consequences of diagenesis and fossilization on bioapatite lattice structure and composition. Chem Geol, 413:18-27. doi: 10.1016/j.chemgeo.2015.08.005

Kohn MJ (2008) Models of diffusion-limited uptake of trace elements in fossils and rates of fossilization. Geochim Cosmochim Ac, 72:3758-3770. doi: 10.1016/j.gca.2008.05.045

LeGeros RZ, Mijares D, Yao F, LeGeros JP, Bromage T, La V, Xi Q, Tannous S, Kijkowska R (2006) Consequences of fluoride incorporation on properties of apatites. Key Engineering Materials 309-311:697-700. doi: 10.4028/www.scientific.net/KEM.309-311.697

LeGeros RZ, Tung MS (1983) Chemical stability of Carbonate- and Fluoride-Containing Apatites. Caries Research 17:419-429. doi: 10.1159/000260696

Li ZY, Lam WM, Yang C, Xu B, Ni GX, Abbah SA, Cheung KMC, Luk KDK, Lu WW (2007) Chemical composition, crystal size and lattice structural changes after incorporation of strontium into biomimetic apatite. Biomaterials 28:1452-1460. doi: 10.1016/j.biomaterials.2006.11.001

Millard AR, Hedges REM (1995) The Role of the Environment in Uranium Uptake by Buried Bone. J Archaeol Sci 22:239-250. doi: 10.1006/jasc.1995.0025

Molodtsov SL, Fedoseenko SI, Vyalikh DV, Iossifov IE, Follath R, Gorovikov SA, Brzhezinskaya MM, Dedkov YS, Puettner R, Schmidt J-S, Adamchuk VK, Gudat W, Kaindl G (2009) Highresolution Russian-German beamline at BESSY. Appl Phys A 94:501-505. doi: 10.1007/s00339008-4916-1

Naftel SJ, Sham TK, Yiu YM, Yates BW (2001) Calcium L-edge XANES study of some calcium compounds. J Synchrotron Radiat 8:255-257. doi: 10.1107/S0909049500019555

Newville M, Ravel B, Haskel D, Rehr JJ, Stern EA, Yacoby Y (1995) Analysis of multiple-scattering XAFS data using theoretical standards. Physica B 208-209:154-156. doi: 10.1016/09214526(94)00655-F

O’Donnell MD, Fredholm Y, de Rouffignac A, Hill RG (2008) Structural analysis of a series of strontium-substituted apatites. Acta Biomater 4:1455-1464. doi: 10.1016/j.actbio.2008.04.018

Pate FD, Hutton JT, Norrish K (1989) Ionic exchange between soil solution and bone: Toward a predictive model. Appl Geochem 4:303-316. doi: 10.1016/0883-2927(89)90034-6 
Pfretzschner HU (2004) Fossilization of Haversian bone in aquatic environments. C R Paleovol 3:605-616. doi: 10.1016/j.crpv.2004.07.006

Politi Y, Arad T, Klein E, Weiner S, Addadi L (2004) Sea urchin spine calcite forms via a transient amorphous calcium carbonate phase. Science 306:1161-1164. doi: 10.1126/science. 1102289

Politi Y, Metzler RA, Abrecht M, Gilbert B, Wilt FH, Sagi I, Addadi L, Weiner S, Gilbert PUPA (2008) Transformation mechanism of amorphous calcium carbonate into calcite in the sea urchin larval spicule. P Natl Acad Sci USA 105:17362-17366. doi: 10.1073/pnas.0806604105

Reiche I, Vignaud C, Menu M (2002) The crystallinity of ancient bone and dentine: new insights by transmission electron microscopy. Archaeometry 44:447-459. doi: 10.1111/1475-4754.00077

Rez P, Blackwell A (2011) Ca L 23 Spectrum in Amorphous and Crystalline Phases of Calcium Carbonate. J Phys Chem B 115:11193-11198. doi: 10.1021/jp203057y

Rodríguez H, Fraga R (1999) Phosphate solubilizing bacteria and their role in plant growth promotion. Biotechnol Adv 17:319-339. doi: 10.1016/S0734-9750(99)00014-2

Smith CI, Nielsen-Marsh CM, Jans MME, Collins MJ (2007) Bone diagenesis in the European Holocene I: patterns and mechanisms. J Archaeol Sci 34:1485-1493. doi: 10.1016/j.jas.2006.11.006

Stavitski E, de Groot FMF (2010) The CTM4XAS program for EELS and XAS spectral shape analysis of transition metal L edges. Micron 41:687-694. doi: 10.1016/j.micron.2010.06.005

Terra J, Dourado ER, Eon JG, Ellis DE, Gonzalez G, Malta Rossi A (2009) The structure of strontium-doped hydroxyapatite: an experimental and theoretical study. Phys Chem Chem Phys 11:568-577. doi: 10.1039/B802841A

Trueman CN (2008) Trace Element Geochemistry of Bonebeds. In: Rogers RR, Eberth DA, Fiorillo AR (ed) Bonebeds: Genesis, Analysis and Paleobiological Significance. University of Chicago Press, Chicago, pp 397-436. doi: 10.7208/chicago/9780226723730.003.0007

Trueman CNG, Behrensmeyer AK, Tuross N, Weiner S (2004) Mineralogical and compositional changes in bones exposed on soil surfaces in Amboseli National Park, Kenya: diagenetic mechanisms and the role of sediment pore fluids. J Archaeol Sci 31:721-739. doi: 10.1016/j.jas.2003.11.003

Tsoukala E, Bartsiokas A (2008) New Mesopithecus pentelicus specimens from Kryopigi, Macedonia, Greece. J Hum Evol, 54:448-451. doi: 10.1016/j.jhevol.2007.10.011 
Turner-Walker G, Nielsen-Marsh CM, Syversen U, Kars H, Collins MJ (2002) Sub-micron Spongiform Porosity is the Major Ultra-structural Alteration Occurring in Archaeological Bone. Int J Osteoarchaeol, 12:407-414 doi: 10.1002/oa.642

Tuross N, Behrensmeyer A K, Eanes E D, Fisher L W, Hare P E (1989) Molecular preservation and crystallographic alterations in a weathering sequence of wildebeest bones. Appl Geochem 4:261-270. doi: 10.1016/0883-2927(89)90027-9

Vekemans B, Janssens K, Vincze L, Adams F, Van Espen P (1994) Analysis of X-ray spectra by iterative least squares (AXIL): New developments. X-ray Spectrom, 23:278-285. doi: $10.1002 /$ xrs. 1300230609

Wopenka B, Pasteris JD (2005) A mineralogical perspective on the apatite in bone. Mat Sci Eng C 25:131-143. doi: 10.1016/j.msec.2005.01.008

Zeglinski J, Nolan M, Bredol M, Schatte A, Tofail SAM (2012) Unravelling the specific site in doping of calcium hydroxyapatite with strontium from $a b$ initio investigations and Rietveld analysis. Phys Chem Chem Phys 14:3435-3443. doi: 10.1039/C2CP23163H

Zougrou IM, Katsikini M, Pinakidou F, Brzhezinskaya M, Papadopoulou L, Vlachos E, Tsoukala E, Paloura EC (2016) Characterization of fossil remains using XRF, XPS and XAFS spectroscopies. J Phys Conf Ser, 712: 012090:1-4. doi: 10.1088/1742-6596/712/1/012090

Zougrou IM, Katsikini M, Pinakidou F, Paloura EC, Papadopoulou L, Tsoukala E (2014) Study of fossil bones by synchrotron radiation micro-spectroscopic techniques and scanning electron microscopy. J Synchrotron Radiat, 21:149-160. doi: 10.1107/S1600577513025228 